This PDF is a selection from an out-of-print volume from the National Bureau of Economic Research

Volume Title: Tax Policy and the Economy: Volume 4

Volume Author/Editor: Lawrence H. Summers, editor

Volume Publisher: The MIT Press

Volume ISBN: 0-262-19296-9

Volume URL: http://www.nber.org/books/summ90-1

Conference Date: November 14, 1989

Publication Date: January 1990

Chapter Title: Implications of Introducing U.S. Withholding Taxes on Foreigner Interest Income

Chapter Author: Lawrence H. Goulder

Chapter URL: http://www.nber.org/chapters/c11574

Chapter pages in book: (p. 103 - 142) 


\title{
IMPLICATIONS OF INTRODUCING U.S. WITHHOLDING TAXES ON FOREIGNERS' INTEREST INCOME
}

\author{
Lawrence H. Goulder
}

Stanford University and NBER

\section{EXECUTIVE SUMMARY}

This paper explores efficiency and equity issues related to the introduction of a withholding tax on foreigners' interest income from their investments in the U.S. Because of existing treaty obligations and taxavoidance options, the effective tax rate of any practicable withholding tax is likely to be considerably below its statutory rate. A statutory 30 percent U.S. withholding tax on portfolio interest, if not accompanied by similar (retaliatory) tax measures introduced by foreign governments, appears to yield aggregate domestic welfare gains. The gains are attributable to U.S. financial market power stemming from the large share represented by the U.S. of world financial transactions and from the imperfect substitutability between U.S. and foreign securities in port-

This paper was prepared for the NBER Conference on Tax Policy and the Economy, Washington, D.C., November 14, 1989. I am grateful to Lans Bovenberg, Don Brean, Daniel Frisch, Alberto Glovannint, Harry Grubert, Jim Hines, Charles McLure, Jack Mutti, and Larry Summers for helpful suggestions. I also thank Margaret Lewis of the Forelgn Returns Analysis Section of the Internal Revenue Service for providing income and tax data, and Philippe Thalmann for both useful comments and excellent research assistance. 
folios. Gains also derive from effects on domestic saving. The withholding tax leads to only a temporary improvement in the U.S. trade balance and in aggregate exports. The ultimate deterioration of the trade balance is closely related to effects of the tax on international interest flows.

If foreign governments respond in kind to a U.S. withholding tax initiative, the combined effect is a decline in U.S. residents' aggregate welfare. Foreign retaliation enlarges the global efficiency losses associated with a new U.S. withholding tax.

The equity arguments for the withholding tax are mixed. Restricting the application of the tax to investors from countries that already impose similar measures may have more justification on fairness grounds than applying the tax to all foreign investors. An attraction of the tax is its ability to discourage capital flight to the U.S. and related tax evasion; however, other policies with less serious efficiency costs might be equally effective in addressing tax evasion problems.

\section{INTRODUCTION}

In the past two decades, the U.S. economy has become significantly more open to international flows of financial capital. As a percent of GNP, gross imports of financial capital-from foreigners' direct and portfolio investments in the U.S. - rose from 0.5 percent in 1965 to 5.0 percent in 1985. These inflows have gradually but significantly altered the pattern of capital ownership in the U.S.: while less than 3 percent of U.S.-located capital was foreign-owned 20 years ago, today foreigners own approximately 7.5 percent of the domestic capital stock.

These developments have given new impetus to discussions about the appropriate tax treatment of foreign-owned capital. Much of the interest income generated in this country now accrues to foreigners, adding importance to the question as to whether such income should be subject to U.S. taxation. Foreign income from U.S. sources has long been subject to a U.S. statutory 30 percent "withholding" tax. However, in July 1984, a major component of the tax was removed with the elimination of withholding taxes on foreigners' interest income from U.S. sources. Recent events have intensified the debate over whether the U.S. should again include foreigners' interest income in the U.S. tax base.

Advocates of taxing foreigners' interest income emphasize that this policy would help diminish the "twin deficits" problem now faced by the U.S. The revenue raised by expanding the withholding tax would help reduce the government budget deficit; at the same time, by discouraging capital inflows, taxing foreigners' interest income would reduce the capital account imbalance and thereby help reduce the trade 
deficit. Discouraging capital inflows, it is argued, reduces demands for dollar-denominated assets, helping to lower the exchange rate value of the dollar and enhancing the international competitiveness of exportoriented domestic industries.

Proponents also maintain that an expanded withholding tax would alleviate problems of tax evasion and capital flight that are particularly troubling for less developed countries. Many foreign individuals and firms now invest in the U.S. in order to escape taxation at home; although in many cases the income from such investments is officially subject to taxation by the home country, such investments are difficult to monitor and evasion is relatively easy. By reducing incentives to invest in the U.S., it is argued, an expanded withholding tax would discourage capital flight from many emerging nations and reduce tax evasion.

Opponents of the policy initiative assert that a tax on foreigners' interest income would in fact raise very little revenue. They point out that bilateral treaties would oblige the U.S. to exempt capital income earned by investors from several nations; they also indicate that even in cases where the U.S. could apply the tax, there are many ways that investors could rechannel their investments to escape taxation. Critics also argue that the tax would curtail domestic capital formation. To attract foreign investors, before-tax interest rates would have to rise (to offset the tax), raising the cost of capital to domestic firms and reducing incentives to invest in plant and equipment.

Many also worry that expanding the withholding tax would give rise to retaliation by other governments, perhaps by way of similar withholding measures, and higher tax burdens on U.S. residents. Others point out that the imposition of withholding taxes-whether by the U.S. or other nations-constitutes an unfortunate departure from the residence principle of taxation according to which governments tax only their own residents. Expanding the withholding tax represents a further departure from this principle. These critics assert that abiding by the residence principle is worthwhile because doing so not only avoids double taxation but also tends to promote a more efficient international allocation of resources.

This paper investigates these issues. The next section begins the investigation by providing some historical background; here the focus is on the previous experience with withholding taxes in the U.S., although some atttention is paid to West Germany's recent experience with such taxes. Section III then provides a framework for evaluating the effects of an expanded U.S. withholding tax. This framework guides the design and interpretation of simulation experiments, reported in Section IV, 
which allow for quantitative assessments of positive and normative effects of such a policy. The fifth section enlarges upon the previous analysis by considering issues of international fairness and possibilities for international policy coordination. The final section offers conclusions.

\section{PREVIOUS EXPERIENCE WITH WITHHOLDING TAXES}

\section{A. Statutory and Effective Rates in the U.S. ${ }^{1}$}

Prior to July 1984, the U.S. levied a 30 percent withholding tax on U.S.sourced income paid to non-resident aliens or foreign corporations. The tax applied to several forms of portfolio income, including interest and dividend income. ${ }^{2}$ However, for several reasons the effective rate was less than the statutory rate. First, several types of interest income were exempt. Interest paid on deposits with domestic banks (including certificates of deposit), savings and loan associations, and similar financial institutions was exempt. The law also exempted interest paid by U.S. corporations earning less than 20 percent of gross income from sources within the U.S., interest paid by insurance companies, and the original issue discount on instruments with a maturity of less than six months (for example, short-term commercial paper and U.S. Treasury bills).

A number of tax treaties further reduced the effective rate. Treaties with 16 countries, including West Germamy and the United Kingdom, assured that residents of these countries paid no U.S. withholding taxes. Residents of 12 other nations faced withholding rates below the statutory rate as a result of bilateral arrangements between their governments and the U.S. government. Other treaty arrangements allowed rate reductions for certain types of income that otherwise would have been subject to the tax. ${ }^{3}$

The revenue potential of the tax was further weakened as a consequence of Internal Revenue Service rulings that enabled U.S. corporate lenders to avoid the withholding tax by setting up finance subsidiaries in

\footnotetext{
1 This subsection draws significantly from Papke (1989), which examines the previous U.S. experience in detail.

2 The tax does not apply to income directly connected with the taxpayer's conduct of trade or business within the U.S. Such income is taxed separately and is treated as if it were received by a U.S. citizen or corporation.
}

${ }^{3}$ See Lewis (1986) for a detailed discussion of treaty arrangements, U.S.-sourced income received, and withholding taxes paid by country. 
the Netherlands Antilles. ${ }^{4}$ The tax was typically avoided by the subsidiary's issuing a Eurobond, free of tax, to a foreign investor, and then funneling the bond revenues to the U.S. parent corporation. IRS rulings in 1974 effectively authorized this practice, even though in these circumstances the subsidiary acted merely as a conduit for the parent. This channel enabled investors from countries without favorable treaty arrangements to purchase U.S. debt without facing the withholding tax. ${ }^{5}$

By 1983, Eurobond issues through the Netherlands Antilles represented nearly all new U.S. corporate bond issues abroad. In that year, interest payments to recipients in the Netherlands Antilles (on previously issued bonds) represented over 33 percent of total interest payments to foreigners. The importance of this tax-avoidance channel gives credence to the comment that the U.S. treaty with the Netherlands Antilles was a "one-way treaty with the world."

Thus, exemptions for certain types of securities, numerous treaty arrangements, and one large loophole greatly eroded the base of U.S. withholding tax. Table 1 shows income payments to foreigners and taxes withheld during the period 1981-1986. Prior to July 1984, the statutory rate on both interest and divided income was 30 percent. However, the table indicates that from 1981 to 1983 , the average tax rate on all U.S.-sourced portfolio income ranges from 6.3 to 7.6 percent, far below the statutory 30 percent rate. The rate on dividends (11.6-12.4 percent) was higher than the rate on interest income (2.1-3.0 percent) during the three-year period. The differences reflect the Netherlands Antilles taxavoidance option (which applied to interest) and the tendency of treaties to specify larger rate reductions for interest payments.

In July 1984, the U.S. repealed the withholding tax on foreigners' portfolio interest as part of the Deficit Reduction Act. The figures for 1985 in Table 1 indicate that the repeal had relatively little influence on the effective tax rate on foreigners' interest income: most of this income already could escape the tax before repeal. On the other hand, repeal had two very significant effects on the method of issuing debt to foreigners. First, it led to a surge in direct sales of debt to non-residents. Quarterly sales of U.S. bonds abroad never exceeded 0.3 billion from the

${ }^{4}$ The Netherlands Antilles is a Caribbean nation comprising the six islands Aruba, Bonnaire, Curacao, St. Maarten, St. Eustatius, and Saba.

${ }^{5}$ Many investors from countries whose treaties with the U.S. would have enabled them to avoid withholding still preferred the Eurobond market. This was the case because Eurobonds could be purchased anonymously; in contrast, to escape withholding by directly purchasing a U.S. bond and taking advantage of favorable treaty terms required that the investor provide information about his or her address and country of residence at every interest payment. 


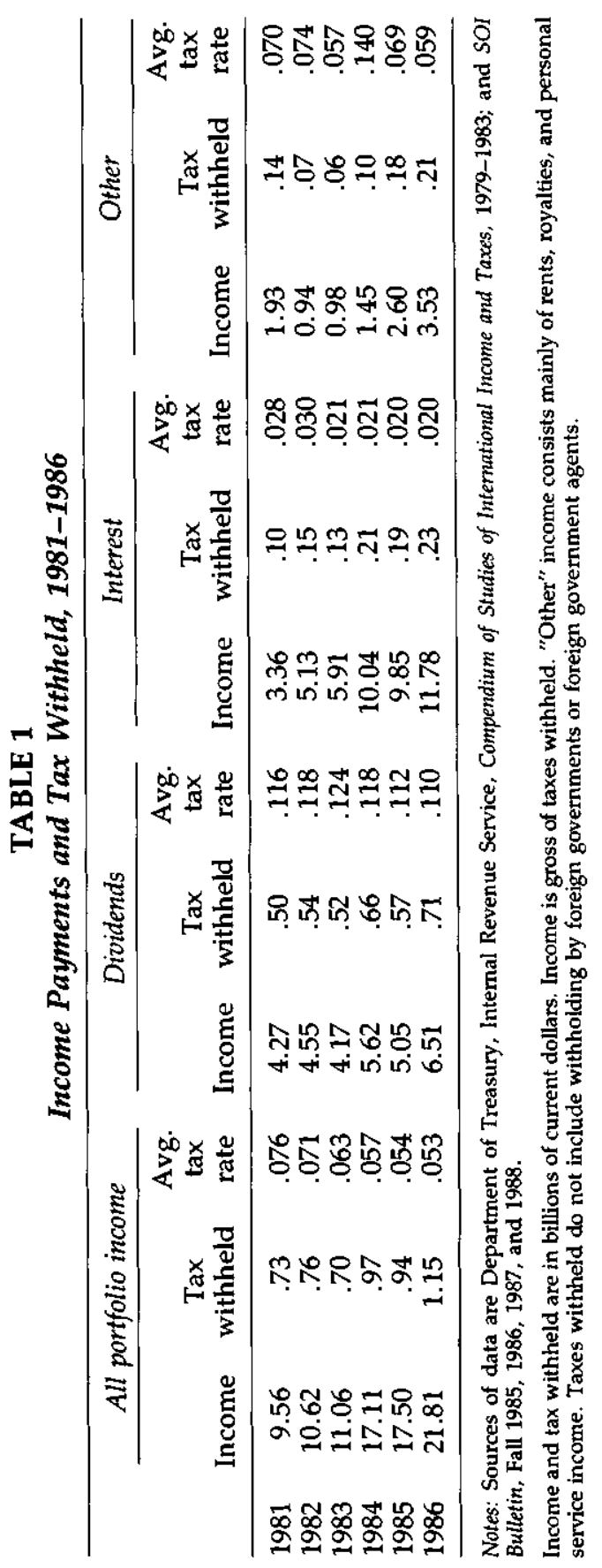


first quarter of 1982 to the second quarter of 1984; in contrast, such sales totaled $\$ 8.4$ billion in the first quarter following repeal of the tax on portfolio interest and have averaged more than $\$ 6$ billion since then. The second main effect was the complete elimination of the use of Netherlands Antilles finance subsidiaries to issue U.S. corporate debt. ${ }^{6}$ This complex tax-avoidance procedure was no longer necessary.

\section{B. The Recent West German Experience}

The U.S. experience reveals the substantial responsiveness of borrowers to changes in international tax rules. Recent events in West Germany also indicate a high degree of responsiveness to tax changes, in this case displayed primarily by the lender side of the market. In the fall of 1987 , the West German government announced that a withholding tax on interest income would go into effect in January 1989. The tax would apply to both resident and non-resident investors in German bond markets. While German domestic bonds (including government bonds) were subject to the tax, foreign securities, including foreign Deutschemark bonds, were exempt. Both resident (West German) and nonresident investors tended to shun the German market soon after the announcement of the tax. In contrast, Deutschemark bonds issued by foreign borrowers were much in demand. The February 1989 Report of the Deutsche Bundesbank stated that the key factor behind the shift toward the foreign bond market by domestic investors "was the fact that these bonds are not subject to withholding tax on interest income." Foreign investors also tended to shift toward the foreign bond market. ${ }^{7}$

These shifts in demand were accompanied by changes in the interest rate differentials between German bonds and other similar securities. While the yield on German Federal bonds typically had been 0.25 to 0.5 percent below the yield on foreign Deutschemark bonds, rates on the former securities rose above those on the foreign bonds beginning in January 1988 (soon after the announcement of the withholding tax).

In April 1989, the German government announced that the withholding tax would be repealed beginning July $1,1989 .^{8}$ The news was fol-

\footnotetext{
${ }^{6}$ For details on these effects, see Papke (1989).

${ }^{7}$ Demand for most types of German bonds sagged, with the exception of German domestic bank bonds, most of which were purchased by German savings banks. Interest received by savings banks were exempt from the withholding tax. For details, see Monthly Report of the Deutsche Bundesbank 41 (2), February 1989.

${ }^{8}$ In repealing the tax, the government adopted the position taken by the Deutsche Bundesbank and various industry groups that withholding had had serious adverse effects on monetary policy and the capital market and therefore could no longer be defended. See Report of the Deutsche Bundesbank for the Year 1988.
} 
lowed by significant responses in both demands and interest rate differentials. Both domestic and foreign investors appeared to shift their portfolios toward the German domestic bond market. For example, while foreign investors reduced their holdings of German public bonds by 7.5 billion marks in the first three months of 1989, in April they took up public bonds totaling more than 4 billion marks. The Deutsche Bundesbank attributed this change to the announced abolition of the withholding tax. ${ }^{9}$ The changes were accompanied by changes in interest differentials. In May 1989, the yield on German Federal bonds fell below that on foreign Deutschemark bonds for the first time since December 1987.

\section{Lessons and Revenue Implications}

The U.S. and West German experiences yield a number of insights regarding the potential effects of prospective changes in the U.S. withholding tax. The U.S. experience brings out the degree to which borrowers may alter financial practices in order to provide untaxed financial instruments and thereby avoid the need to offer higher yields to investors. In West Germany, tax avoidance was accomplished less by firms' changing their methods of financing and more by lenders' shifting away from the securities offered by German firms or banks.

Together, these experiences reveal a substantial potential for taxavoidance behavior on both sides of the market. The attractiveness of expanding the withholding tax depends importantly on its revenue yield, and if a U.S. tax on foreign interest is going to yield significant revenues, the tax will have to be more difficult to escape than its predecessor.

Could a U.S. withholding tax on foreigners' interest be implemented in a way that yields significant revenues? Certainly in one important respect, the revenue potential of the tax could be enhanced easily-by proscribing the establishment of finance subsidiaries (in the Netherlands Antilles or elsewhere) for the purpose of avoiding withholding. This would not pose administrative problems, and would substantially shrink, if not eliminate, an important loophole. ${ }^{10}$

However, broadening the base of the tax might prove to be more difficult. Extensive base broadening would require renegotiating exist-

\footnotetext{
${ }^{9}$ See Monthly Report of the Deutsche Bundesbank 41 (7), July 1989.

${ }^{10}$ It is unlikely that the prohibition could be made air-tight, given the difficulty of establishing whether the parent company's main reason for creating a given subsidiary was tax avoidance.
} 
ing treaties that exempt residents of certain countries from U.S. withholding. In view of the political costs of such initiatives, this may not be a realistic option. The success of this option would also be dampened to the extent that some foreigners reduced their tax obligations by setting up "tax residences" in countries other than their main country of residence-namely, in countries with particularly advantageous treaties with the U.S. This suggests that the revenue potential of a withholding tax on foreigners' portfolio interest will be compromised so long as there are a few countries whose treaties with the U.S. continue to offer their residents particularly favorable withholding rates.

Another potential way to expand the revenue of the tax is to broaden the domain of financial instruments covered by the tax. A main candidate for such broadening is interest on bank deposits. However, attempts to broaden the tax in this way might encounter substantial opposition. Some have questioned the advisability of extending the tax to interest received on bank deposits in view of the fact that some depositors are financial intermediaries, both lenders and borrowers. The claim is that banks and other firms engaged in financial intermediation should be given a tax deduction on interest paid to offset the tax on interest received. It is argued that for such firms, a tax on gross interest amounts to a tax on gross income and is effectively a tax on financial intermediation itself. This is considered unfair to the intermediaries; only a tax on net income is considered legitimate. ${ }^{11}$ However, it might be difficult for the U.S. to administer a tax that applies only to net interest. Many financial intermediaries would claim interest deductions for payments made to foreign investors, and such payments would be difficult for the U.S. government to verify.

These considerations motivate some calculations of the potential additional revenues from expanding the withholding tax. First, suppose withholding were expanded by introducing a tax on portfolio interest with the same features (similar tax base, similar loopholes) as the portfolio interest tax that applied prior to July 1984 . Table 1 showed that the effective rate on portfolio interest changed very little after repeal. In 1983 , the effective rate was 2.1 percent; in 1985 and 1986, 2.0 percent. A reasonable assumption is that resurrecting the type of interest withholding that applied prior to repeal would raise the effective rate by 0.1 percentage points; such an increase in the effective rate implies an additional $\$ .02$ billion for the year 1990 , assuming gross portfolio interest

${ }^{11}$ It may be noted that the West German withholding tax exempted "domestic bank bonds," most of which were purchased by German savings banks. 
payments to foreigners in 1990 of $\$ 20.9$ billion. ${ }^{12}$ Alternatively, one might project the revenue effects by assuming that the extension of withholding restores the average rate on all U.S. source portfolio income to the rate which applied prior to repeal. This alternative approach suggests that extending the withholding tax would imply an additional $\$ .2$ billion for the year $1990 .{ }^{13}$ These simple calculations suggest that an interest withholding tax of the type that applied prior to July 1984 would not yield significant revenues. Moreover, these calculations probably overstate the net revenue effect from such an expansion of the tax: to the extent that the tax on interest income induces a rise in before-tax U.S. interest rates, it raises the value of interest deductions from the U.S. corporate income tax, implying an offsetting revenue loss. ${ }^{14}$

Some simple further calculations give a rough idea of the potential additional revenues that might be generated by removing loopholes and broadening the base of the portfolio interest tax. These calculations will be crude in that they will assume the tax does not alter the level and composition of gross income payments to foreigners. ${ }^{15}$ The implications of removing the Netherlands Antilles loophole can be gauged by raising the effective rate to Netherlands Antilles recipients from 0.44 percentthe effective rate on income to recipients in this country in 1983-to 7.69 percent - the average effective rate to recipients from other countries. ${ }^{16}$ Doing so implies additional revenues of $\$ 0.49$ billion. The effects of removing the favorable provisions of treaties can be assessed in similar fashion: by replacing the 1983 average effective rate to treaty countries ( 7.50 percent) with the average rate that applied to non-treaty countries

12 The value of 1990 interest payments to foreigners was projected from the actual payments level in 1987 assuming an annual growth rate of 22.5 percent, the average annual rate over the period 1981-1987.

${ }^{13}$ This alternative approach assumes that the composition of foreigners' holdings of U.S. assets would be the same after reintroducing interest withholding as it was in 1983 (prior to repeal). In 1983, the average effective withholding tax rate (Table 1) was 6.3 percent; in 1987, the most recent year for which such data are available, the average effective rate was 5.7 percent. If restoring interest withholding raised the overall rate by 0.6 percentage points in 1990 , it would thereby generate $\$ 0.2$ billion, assuming gross income payments to foreigners in 1990 of $\$ 35.1$ billion. The 1990 gross income figure was projected from the actual payments level in 1987 assuming an annual growth rate of 15.5 percent, the average annual rate over the period 1981-1987.

${ }^{14}$ See Brean (1984) for an examination of this issue.

${ }^{15}$ These calculations probably overstate potential additional revenues, since agents are likely to alter savings instruments and shift methods of financing in order to reduce their tax obligations.

${ }^{16}$ Figures for average withholding tax rates for different countries were obtained from Carson (1985). Withholding by foreign governments or foreign withholding agents is not considered. 
(10.01 percent). This implies additional revenues of $\$ 0.96$ billion. ${ }^{17} \mathrm{Fi}-$ nally, withholding interest payments on bank deposits could bring in further revenues. Applying an effective rate of 30 percent to estimated U.S. bank deposit interest to non-bank foreigners in 1990 implies an additional $\$ 3.1$ billion in revenues. ${ }^{18}$

Thus, these crude calculations suggest that expanding the withholding tax might raise from $\$ 0.02$ to $\$ 4.75$ billion in additional annual revenues, depending on the extent of loophole-closing and basebroadening. Bank deposits appear to represent the largest potential source of new revenues.

Of course, the revenue potential of an expanded withholding tax is only one of several important considerations relevant to assessing the effects of the policy option on economic well-being. The next section brings out other critical considerations.

\section{A FRAMEWORK FOR EVALUATING WITHHOLDING TAXES}

This section presents a framework for analyzing potential effects of changes in withholding taxes on the domestic economy. The focus is on domestic welfare.

We begin with the case that is simplest to analyze: here we abstract from the possibility of U.S. market power in world capital markets and from pre-existing taxes on domestic saving or domestic investment. We also abstract from the presence of tax credits offered by foreign governments and from the possibility of retaliation (for example, imposing new taxes on U.S. residents' investments abroad) by foreign governments. Subsection $B$ below extends the analysis to consider these complications.

\section{A. The Simplest Case}

In the simple case considered here, the U.S. is regarded as a price taker in international markets for financial capital. In Figure 1, the horizontal line $S_{F 1}$ represents the original supply curve of financial capital; in keeping with the price-taker assumption, the supply is perfectly elastic at the

${ }^{17}$ To avoid double-counting, the additional income is calculated by employing an adjusted average rate for treaty countries. This rate is calculated after adjusting taxes paid by Netherlands Antilles recipients to incorporate the assumption that the finance subsidiary loophole had been removed.

${ }^{18}$ Gross interest payments on bank deposits were projected from data on demand and time deposits of non-bank foreigners published in the 1985 Treasury Bulletin. An interest rate of 8 percent was assumed. 


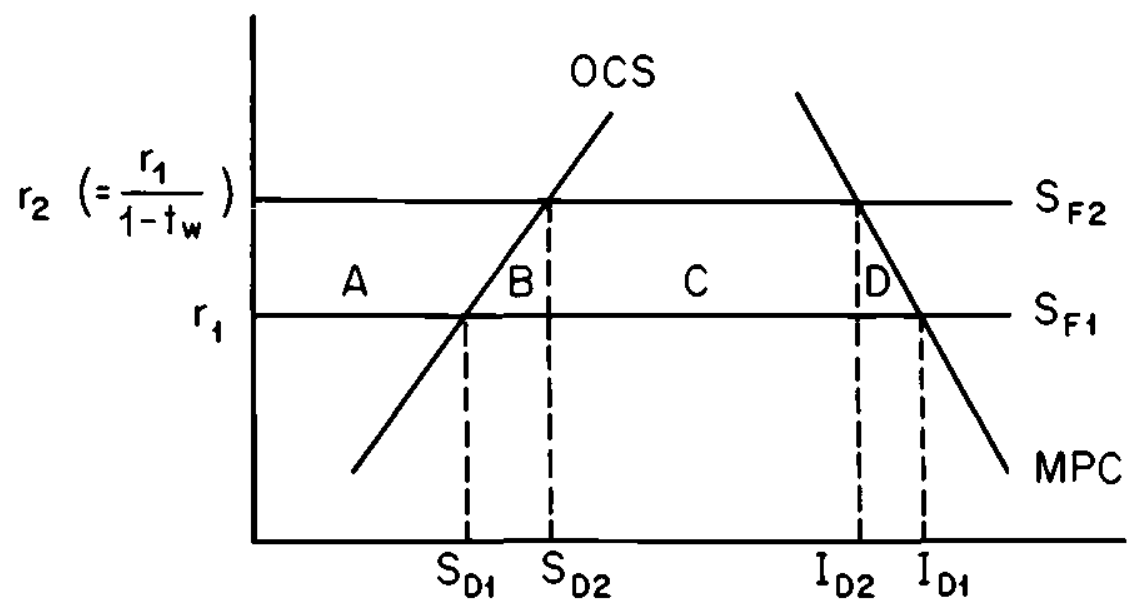

FIGURE 1. Effects of Withholding Taxes: The Simplest Case

world interest rate $r_{1}$. The downward and upward sloping lines represent the marginal product of capital (MPC) and opportunity cost of saving (OCS) as functions of the levels of domestic investment and domestic saving, respectively. ${ }^{19}$ In the absence of a withholding tax and of other taxes, equilibrium in the capital market is established with domestic saving equal to $S_{D 1}$, domestic investment equal to $I_{D 1}$, and imports of capital equal to $I_{D 1}-S_{D 1}$.

If the U.S. alters this environment by imposing a withholding tax, the pre-tax return offered to foreign investors must rise to $r_{2}=r_{1} /\left(1-t_{w}\right)$, where $t_{w}$ is the withholding tax rate; the increase in the pre-tax return is necessary to make the after-tax return to foreign investors comparable to the return these investors could obtain elsewhere. Thus, the foreign supply curve rises to $S_{F 2}$. The higher gross rate reduces investment demands to $I_{D 2}$ and stimulates a higher level of domestic saving, $S_{D 2}{ }^{20}$ Hence imports of financial capital fall.

\footnotetext{
${ }^{19}$ It is not necessary to specify the time frame for the saving and investment schedules employed here. What is critical is that OCS and MPC respectively take into account all future consumption alternatives and the productiveness of a current investment over all future points in time.

${ }^{20}$ We assume here that U.S. firms are unable to discriminate between domestic and foreign lenders when they issue securities. Thus, the higher gross return must be offered to both classes of lenders. This assumption seems well substantiated by empirical observation.

This partial equilibrium analysis assumes that increases in the after-tax interest rate bring about a higher volume of saving. In general equilibrium, this need not be the case
} 
The tax has the following welfare effects. The higher returns offered to domestic savers yield a welfare gain to these savers which is represented by the area $A$. Domestic firms face higher costs of borrowing, and suffer a welfare loss represented by regions $A, B, C$, and $D$ taken together. The revenues collected by the tax yield a gain to taxpayers which is represented by $C{ }^{21}$ In the aggregate, the tax yields a domestic welfare loss of $B+D . B$ is the dead-weight loss associated with the domestic economy's having to finance $S_{D 2}-S_{D 1}$ of domestic investments at a rate higher than the world interest rate, $r_{1}$, and yet not collecting any withholding tax on these investments. $D$ is the dead-weight loss associated with no longer undertaking marginal investments $I_{D 1}-I_{D 2}$, whose returns exceed the world interest rate.

This initial, simple analysis indicates that if the U.S. is a price taker in international capital markets and if one abstracts from possible complications posed by foreign tax credits and other taxes, then imposing a withholding tax will not improve aggregate domestic welfare. The analysis here is similar to that which applies to the introduction of an import tariff in an economy that is a price taker in commodity markets. Of course, the withholding tax redistributes wealth and welfare, and this enables some agents-for example, savers and taxpayers-to gain. And certain U.S. industries may benefit (in terms of profitability or sales) from the tax change. Export-oriented industries, in particular, may gain. The reduction in capital imports occasioned by the tax reduces demands for dollar-denominated assets and thus tends to make the dollar cheaper in international exchange markets. This will tend to benefit domestic industries oriented toward the export market, at least initially. ${ }^{22}$

(see, for example, Bovenberg (1989a)). Possibilities of shifts in the saving schedule as a result of general equilibrium effects do not alter the aggregate welfare analysis presented here.

${ }^{21}$ The taxpayer's gain may occur in one of two ways. The tax revenues may permit the government to maintain the same real expenditure while lowering other taxes by the amount raised by the withholding tax. Alternatively, the government may use the revenues to provide additional goods and services valued by taxpayers. In this latter case, $C$ accurately represents the welfare gain to taxpayers only if the value to them of a dollar of additional public expenditure equals the value to them of a dollar of private expenditure. If the government is inefficient in its use of tax revenues, the gains to taxpayers will be lower, but the essential aggregate welfare conclusions from the analysis do not change.

22 Because the withholding tax reduces domestic investment, the policy ultimately implies a lower capital stock than otherwise would be the case. Over the longer term, the lower stock may imply reduced real incomes and reduced demands for the products of all industries, including export-oriented industries. Using a dynamic simulation model, Goulder and Eichengreen (1989a) and Bovenberg and Goulder (1989) find that, because of capital accumulation effects, investment-oriented policies have opposite implications for the output and profitability of export industries in the short and long run. 


\section{B. Complications}

1. U.S. Market Power. The above analysis assumed that the U.S. is a small actor in world financial markets. This clearly is not the case. In 1988 , securities issued by the U.S. amounted to $\$ 47.2$ billion, approximately 14.3 percent of the total value of securities issued by the OECD nations. ${ }^{23}$ This large share of the supply side of the market suggests considerable monopsony power: changes in U.S. demands for investible funds (supplies of securities) are likely to have a significant effect on world interest rates.

The large market share is not the only potential source of market power. Such power also arises if foreign investors cannot perfectly substitute securities issued by the U.S. for foreign securities. Under these circumstances, foreign interest rates and the U.S. rate (after withholding) will not be brought to equality following the introduction of a withholding tax: investors will not sufficiently shift toward foreign securities to drive the foreign rate down to match the U.S. rate net of withholding. Hence imperfect substitutability also grants market power to the U.S. because it allows the withholding tax to drive down U.S. interest rates (after withholding). In the extreme case where foreign investors cannot substitute foreign securities for U.S. securities to any degree, the withholding tax need not cause pre-tax rates to rise at all: that is, the after-tax rate can fall by the full amount of the tax without causing any reduction in the supply of foreign funds to the U.S. ${ }^{24}$

For a nation with the power to influence after-tax interest rates, it is no longer the case that a withholding tax will necessarily reduce aggregate welfare. As shown in the appendix, the aggregate welfare effects now must take account of the effects of withholding on the domestic after-tax rate and the foreign interest rate. The larger is a nation's share of the world capital market, the greater its ability to drive down interest rates. If the nation is a net capital importer, reduced interest rates tend to reduce the costs of net capital imports. This implies a welfare benefit that to some degree will offset the adverse aggregate welfare effects of introducing withholding. In contrast, for a net capital exporting country, larger market share tends to reduce the attractiveness of withholding by reducing the returns from net capital exports.

Imperfect substitutability generally makes withholding more attrac-

${ }^{23}$ This information was obtained from OECD Financial Statistics, Part 1, Financial Statistics Monthly, January 1989.

${ }^{24}$ This abstracts from income effects. By reducing foreigners' incomes, the withholding tax could depress the overall level of foreign saving and thereby exert some compensating upward influence on world interest rates. 
tive. This is the case because it generally allows the domestic after-tax interest rate-the rate paid to import capital-to fall by more than the world interest rate-the rate received on exported capital. Thus, the lower the substitutability between domestic and foreign securities, the higher the net interest income following the introduction of withholding. ${ }^{25}$

2. Foreign Tax Credits. The tax systems of many nations include provisions which would permit their residents to credit withholding taxes paid to the U.S. against tax obligations to the foreign government. Indeed, all of the OECD nations offer some type of credit for taxes paid by their residents to other governments, although in many cases the credit provisions are rather restrictive.

The presence of foreign tax credits can substantially alter the effects of U.S. withholding taxes. If marginal foreign investors in the U.S. are eligible for full crediting of the withholding tax, then imposing the tax in the U.S. will lead to no change in the pretax rate of return offered on U.S. securities. The tax payment to the U.S. government in this case is fully offset by a lowered tax liability to the relevant foreign government. The overall return to the foreign investor (net of U.S. and foreign taxes) is unchanged.

Under these circumstances, the withholding tax would have no firstorder effect on domestic pre-tax interest rates or on the level of domestic saving and investment. What the tax accomplishes is a transfer of revenues from foreign nations to the U.S. If one believes that foreign governments would not respond to this U.S. initiative by imposing similar withholding taxes on U.S. investors, then the U.S. withholding tax appears quite attractive from the point of view of domestic welfare.

However, it is important to note that these results obtain only if the marginal foreign investor is eligible for the tax credit. Even if a large number of investors in U.S. securities can take advantage of the credit, if the marginal investor cannot, then domestic borrowers will need to increase pre-tax interest rates to attract the necessary additional lenders. In this case, introducing U.S. withholding directly affects the equilibrum in the domestic loanable funds markets, as in the cases previously described.

3. Pre-existing Taxes on Domestic Saving or Domestic Investment. The previous analysis abstracted from important prior taxes on domestic

${ }^{25}$ As indicated in the appendix, evaluating the welfare implications of lower asset substitutability also requires consideration of the effects of lower substitutability on the levels of capital imports and exports. 
saving and investment. The U.S. individual income tax drives a wedge between the gross and net return to saving by domestic households. The U.S. corporation income tax (including depreciation provisions) imposes a wedge between the gross and net return (at the level of the firm) from investments. ${ }^{26}$

In the presence of these other taxes, introducing a withholding tax may have quite different welfare implications from those originally derived. Prior taxes influence both the aggregate welfare impact and the distribution of the gains and losses. As shown in the appendix, the implications of prior saving taxes are different from those of prior taxes on investment. Prior taxes on (subsidies to) saving exert a positive (negative) influence on the net welfare impact of a withholding tax. To the extent that a withholding tax raises interest rates to domestic savers, it may stimulate additional domestic saving. This enables the saving tax to bring in more revenue. The additional revenue from the saving tax corresponds to a welfare gain. The welfare benefit occurs because taxes on saving cause the marginal social opportunity cost of a given level of saving to fall below the marginal social benefits (private return plus value of taxes) associated with that level of saving: at the margin, a unit of saving is worth more to individuals and taxpayers than its cost in terms of foregone consumption. Hence, there are welfare gains that stem from the increase in domestic saving induced by the withholding tax.

Similar considerations indicate that prior taxes on (subsidies to) investment reduce (increase) the appeal of withholding. Higher interest rates from the imposition of withholding tend to discourage domestic investment. In the presence of investment taxes, the decline in investment implies an additional welfare loss because, with such taxes, the marginal social benefit from investment exceeds its marginal social cost. Saving and investment taxes alter the distributional implications of a withholding tax by changing the relative magnitudes of domestic saving and investment in the initial equilibrium prior to the introduction of withholding.

4. Substitutions between Taxed and Untaxed U.S. Securities. As indicated in Section ll, it is unlikely that any practicable U.S. withholding tax would effectively cover all U.S. securities. Assets might escape the tax

${ }^{26}$ For a detailed discussion of these "wedges," see King and Fullerton (1984). Sinn (1988) analyzes these issues in an open-economy context. Accelerated depreciation and other favorable tax provisions applied to investment raise the possibility that the overall wedge posed by investment-side tax policies may be negative (see Sinn [1988]). 
by substitution activities undertaken by either borrowers or lenders. The use of Netherlands Antilles finance subsidiaries represented borrowers' substituting one financing channel for another in order to avoid the tax. Foreign investors' substituting untaxed U.S. certificates of deposit for taxed corporate bonds exemplifies a tax-avoidance response on the lender side of the market. Either type of substitution implies lower effective withholding tax rate than that employed in the previous analysis. In the polar case of perfect substitutability, the effective rate is zero: the introduction of the tax precipitates a complete switching to untaxed securities, so there is no first-order change in the equilibrium levels of domestic saving or investment.

How much substitution is possible? This depends both on the design of the tax and on preferences. Tax legislation might proscribe the use of alternative financing channels (as in the Netherland Antilles case) to avoid tax. However, unless the tax covers all financial assets, lender-side substitution is inevitable.

\section{Divining the Overall Effects in a Complicated Environment}

The different "complications" considered above make it difficult to assess $a$ priori the effects of a new withholding tax. Table 2 summarizes the ways these different dimensions of the economic environment influence the welfare analysis. As the table makes clear, some of these complications-namely, U.S. market power and prior taxes on saving - tend to exert positive influences on welfare, offsetting the negative overall impacts implied by the original "simplest case" analysis and the negative influence of prior investment taxes. Thus, in a complex environment, the overall impact of a withholding tax is analytically ambiguous. The overall impact depends on the relative importance of the often contradictory forces at work.

Ascertaining the overall effects requires a quantitative analysis: data and behavioral parameters have to be supplied. The next section discusses the design and results of a quantitative approach intended to shed further light on welfare and other effects of a new withholding tax.

\section{SIMULATIONS}

\section{A. The Model}

The simulation results described here derive from a simulation model of the U.S. and the "rest of the world." The model is general equilibrium in nature, accounting for interactions among labor, capital, and goods markets in the U.S. and foreign economies. It acknowledges the openness of 
TABLE 2

Significance of "Complicating Factors"

Factor

Significance

U.S. Power in Financial

Markets

- large share of world transactions

-imperfect substitutability between domestic and foreign securities

Tax Credits Offered by Foreign

Governments

-marginal investor fully eligible for credit

- marginal investor not fully eligible for credit

Pre-existing Taxes on Domestic Saving or Investment

Substitution between Taxed and Untaxed U.S. Securities

enables withholding tax (WHT) to cause reduction in domestic and foreign interest rates; makes WHT more (less) attractive if U.S. is net importer (exporter) of capital.

enables WHT to induce reduction in domestic interest rate relative to foreign rate; makes WHT more attractive

enable WHT to transfer funds from foreign to domestic treasuries; imply WHT has no first-order effect on domestic saving or investment enable WHT to transfer funds from foreign to domestic treasuries; imply WHT has some effect on domestic saving and investment

prior saving taxes expand potential of WHT to generate welfare gains; prior investment taxes reduce this potential

implies lower effective withholding tax rate

the U.S. economy by paying close attention to U.S. international trade in commodities and in financial capital.

The model's structure and data are fully described in Goulder and Eichengreen (1989b). Here we offer only a brief description of the model, emphasizing the features most relevant to analyzing withholding taxes.

The production side of the model distinguishes ten U.S. industries and one foreign industry. At each point in time, domestic and foreign producers combine cost-minimizing levels of labor and intermediate inputs with the existing capital stock. Intermediate inputs can be obtained both at home and abroad, and firms choose the mix of domestic and foreign inputs that minimizes costs.

Industry capital stocks evolve over time as a result of managers' forward-looking investment strategies aimed at maximizing the value of the firm. Optimal investment involves balancing the costs of new capital 
(both the acquisition costs and the adjustment costs associated with installation) against the benefits in terms of the higher gross profits made possible by a larger capital stock. ${ }^{27}$ Investments are financed through retained earnings and new issues of debt and equity. Managers have perfect-foresight expectations; thus their investment decisions take account of future prices and interest rates as well as current conditions.

The consumption side of the model includes a representative domestic household and a representative foreign household. Each household makes consumption and portfolio decisions to maximize utility. Like producers, households are forward-looking (with perfect foresight), basing their decisions on future as well as current prices and interest rates. The model takes account of international cross-ownership of financial assets. Portfolios of foreign households, for example, generally consist of both foreign and U.S. stocks and bonds. Similarly for U.S. households.

Households' portfolio decisions include choosing the shares of domestic and foreign assets in their financial wealth. When relative rates of return offered on domestic and foreign assets change, households adjust their portfolios to increase the share of portfolios represented by assets whose relative returns have increased. For a given household, overall consumption at each point in time is a composite of specific consumption good types which in turn are composites of domesticallyproduced and foreign-made goods of each type. When the relative prices of domestic and foreign consumer goods change, households alter the proportions of domestic and foreign consumer goods making up each composite in accordance with utility maximization.

Household labor supply is exogenous. Households supply labor only to firms in the country of residence: labor is internationally immobile. However, labor is perfectly mobile across industries within a country.

The model also incorporates a government sector in both the domestic and foreign economies. Each government collects taxes, distributes transfers, purchases goods and services, and faces a budget constraint according to which revenues and expenditures must balance in each year.

The requirements of equilibrium are that in each country and in each period of time: (1) the demand for labor equals its supply, (2) the demand for output from each industry equals its supply, (3) total external borrowing by firms equal total saving by residents of the given country

${ }^{27}$ The model adopts the asset price approach to investment of Summers (1981), which incorporates considerations of adjustment costs within a $q$-theoretic firm-valuemaximizing investment framework. 
plus the net capital inflow, and (4) government revenues equal government spending. Equilibrium is established through adjustments in the nominal exchange rate, ${ }^{28}$ in domestic and foreign output prices, in domestic and foreign interest rates, and in lump-sum adjustments to domestic and foreign personal taxes.

New policies lead to changes in prices, interest rates, and asset values in the U.S. and abroad. Such changes induce households to alter their expenditure patterns and their portfolios. Through adjustments in asset prices, interest rates, and exchange rates, a new equilibrium is established in which asset, commodity, and factor supplies and demands are in balance.

\section{B. The Experiments}

We consider two main policy changes. The first is the unilateral introduction by the U.S. of a 30 percent withholding tax on foreigners' portfolio interest; the second is the introduction of such a tax accompanied by a similar 30 percent tax adopted by foreign governments. The previous section indicated several factors which condition the effects of a withholding tax. These factors are addressed in the following "central case" assumptions (which are altered in subsequent sensitivity analysis):

1. U.S. Power in Financial Markets. This depends on the U.S. share of world financial capital and the substitutability of U.S. and foreign assets. The simulations assume that the U.S. initially (prior to the policy change) issues 30 percent of securities issued worldwide. The elasticity of substitution between U.S. and foreign assets in portfolios is assumed to be unity.

2. Tax Credits Provided by Foreign Governments. Marginal investors are assumed to be ineligible for such credits. However, the credits do apply to inframarginal investments (and give rise to international revenue transfers). Credits are assumed to apply to 60 percent of the value of taxes withheld.

3. Pre-existing Taxes. The model incorporates detailed aspects of the U.S. tax system. The "foreign tax system" has the same structure as that in the U.S., although its tax rates generally differ from the U.S. counterparts.

${ }^{28}$ The number of equilibrating "prices" is one less than the number of equilibrium conditions, as one of the equilibrium conditions is redundant from Walras's Law. Both domestic and foreign nominal wages are fixed in their respective currencies. The exchange rate variable permits the relative prices of domestic and foreign labor to vary. 
4. Substitutions between Taxed and Untaxed U.S. Securities. The model's capabilities for evaluating withholding taxes are weakest with respect to this issue. Although it represents corporate stocks and bonds explicitly, the model does not explicitly deal with bank deposits or financial intermediation. Thus it cannot explicitly capture substitutions between such deposits and other assets. Nor does the model directly consider borrower-side tax avoidance through establishment of subsidiaries in tax-haven countries. These issues are addressed primitively and indirectly through the assumption that the effective withholding tax rate is 75 percent of the statutory rate.

\section{Results}

1. Unilateral Withholding Tax. Table 3 displays some principal macroeconomic effects from these simulations. We begin with the effects of a U.S. withholding tax initiative unaccompanied by foreign retaliation.

a. Macroeconomic effects. The U.S. withholding tax tends to generate an increase in U.S. saving (and consumption) and a decline in foreign saving (and consumption). This partly reflects the fact that the policy change raises permanent income of domestic residents and reduces the permanent income of foreigners (discussed in b below). At the same time, the policy change induces foreigners to devote larger shares of their portfolios to foreign, rather than U.S., assets. Thus, changes in both the levels and composition of saving imply a deterioration of the U.S. capital account balance. In the base (or status quo) case, the capital account balance is zero. The policy change implies capital account deficits.

The reduction in foreign demand for U.S. assets has two direct consequences. First, it promotes increases in the U.S. before-tax interest rate. This is shown in Figure 2a, which compares the paths of this interest rate under the policy change with its (constant) path in the base case. The second direct effect is a reduction in the exchange rate value of the dollar; this leads to a parallel reduction in the real exchange rate (price index of domestic goods divided by the price index of foreign goods).

The capital account deficit must be financed by a surplus on the current account, whose components are the trade balance and the net interest receipts from abroad. The policy change reduces the value of interest paid to foreigners; net interest receipts are positive immediately following the policy change. However, in the short run, the improvement in this component of the current account is not sufficient to finance the capital account deficit; hence the U.S. must run a trade surplus. However, as the U.S. continues to run capital account deficits, net interest 


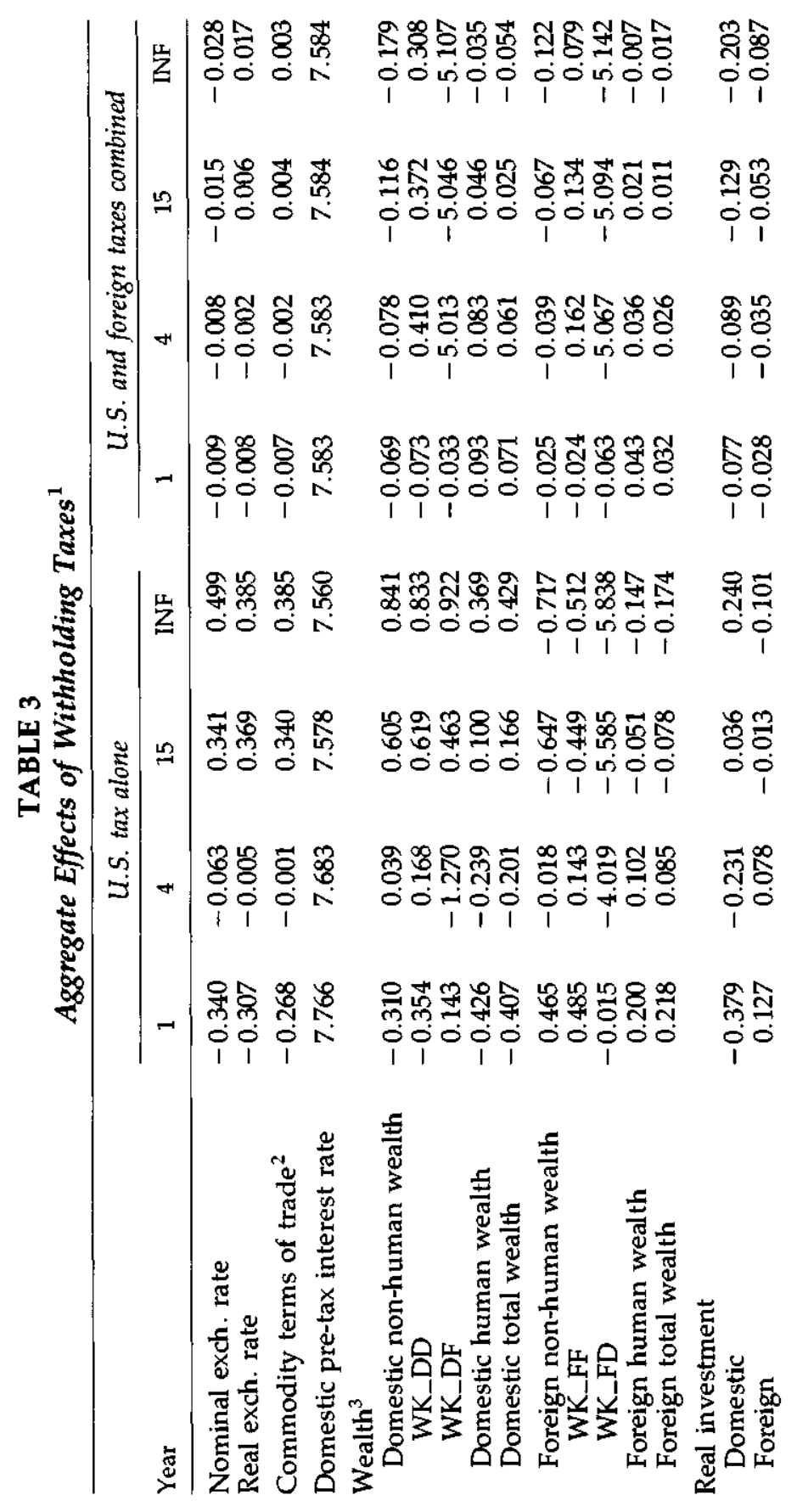




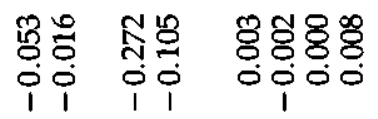

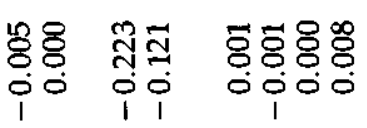

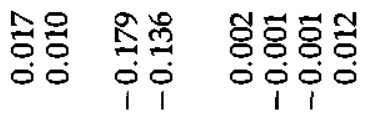

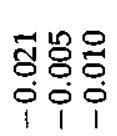

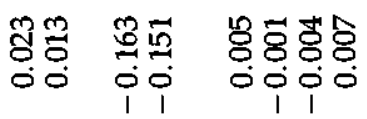

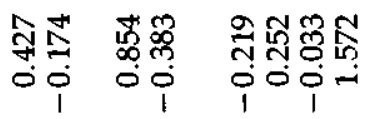

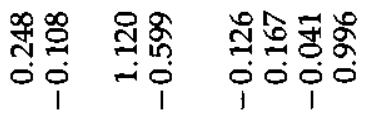

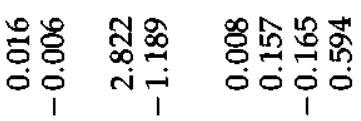

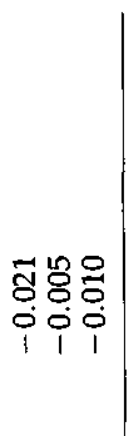

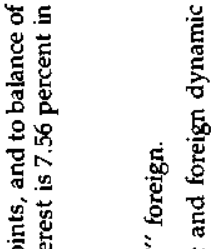

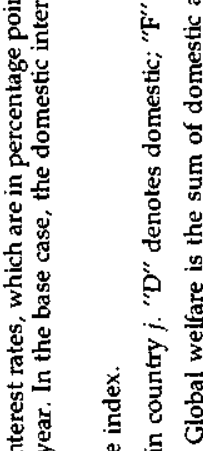

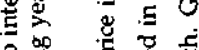

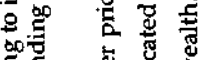

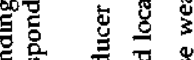

总总

可

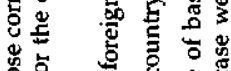

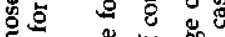

至言 点

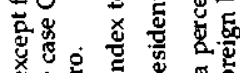

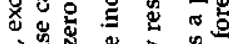

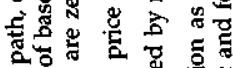

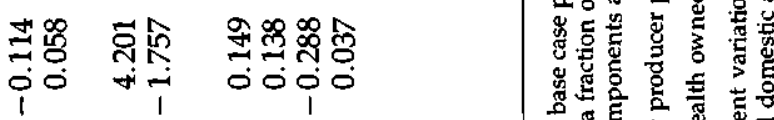

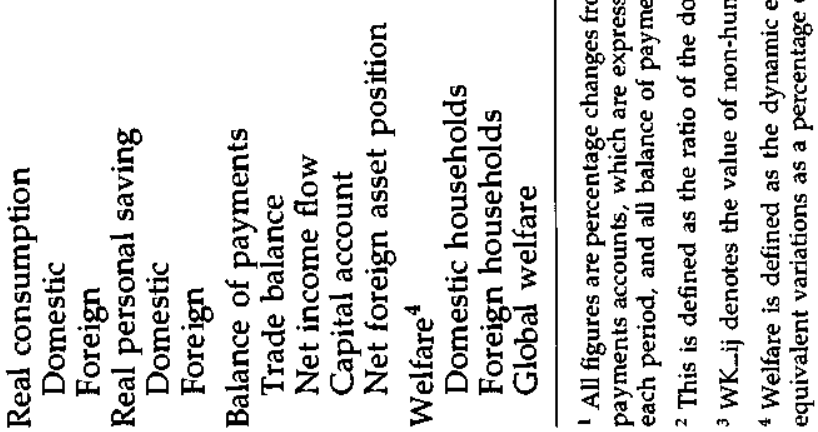


a) U.S. Before-Tax Interest Rate

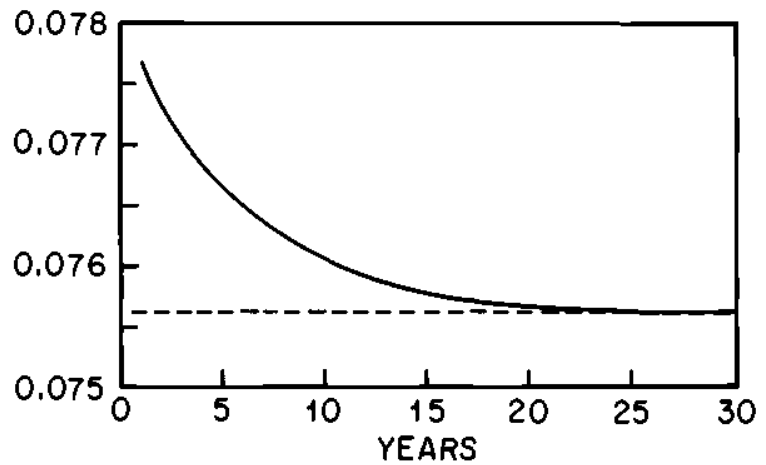

b) U.S. Trade Balance

percent

c) U.S. Aggregate Real Exports

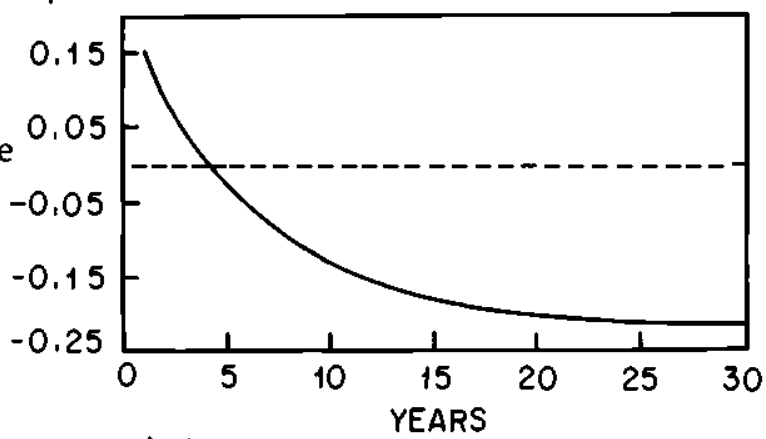

percent change

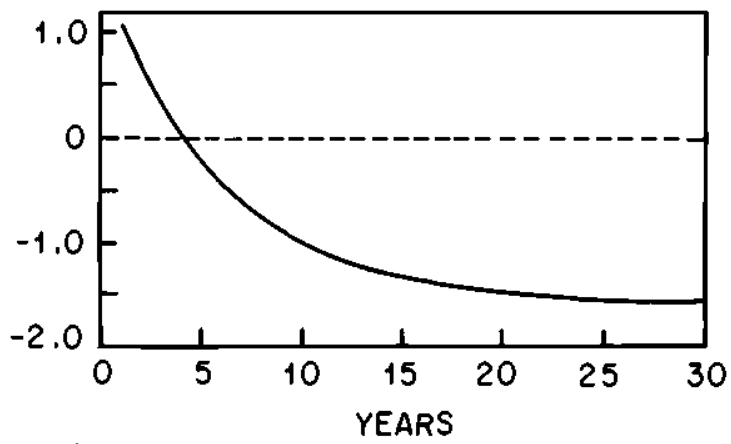

FIGURE 2. Dynamic Effects of Withholding Taxes

flows from abroad continue to rise both absolutely and relative to GDP. After a few years, this permits the U.S. trade balance to switch to a deficit, as indicated in Figure $2 \mathrm{~b}$. Thus the effects of the withholding initiative on the trade balance change dramatically over time.

On impact, the policy change improves the net foreign asset position of the U.S. - the value of U.S. -owned assets located abroad relative to 
foreign-owned assets located in the U.S. This occurs because the withholding tax significantly reduces the after-tax value of foreigners' holdings of U.S. assets. The improvement in the U.S. asset position also means that the nation needs to export less to meet its obligations to foreigners. ${ }^{29}$

By raising U.S. pre-tax rates relative to foreign rates, the policy change reduces the rate of domestic investment relative to foreign investment. Over time, this reduces the relative supply of U.S. goods, and tends to raise their relative price, as indicated by the gradual increase in the real exchange rate (after its initial drop). These exchange rate movements help to bring about the necessary changes in the trade balance. They also imply reductions (relative to the base case path) in aggregate real exports in the long run (Figure $2 \mathrm{c}$ ).

b. Welfare effects. The bottom rows of Table 3 display welfare effects. The policy initiative raises aggregate domestic welfare; this suggests that the positive welfare effects associated with market power and (in the presence of prior saving taxes) increased domestic saving are strong enough to offset the distortionary costs of the policy. Foreigners suffer a decline in welfare. Global welfare-here defined as the sum of the dollar-equivalent welfare changes to domestic and foreign residents-also declines, suggesting that the policy change reduces the global efficiency of resource allocation. (Section $\mathrm{V}$ below offers explanations for the global efficiency effects.)

2. U.S. Tax with Foreign Retaliation. The right-hand columns of Table 3 display results under the assumption that the U.S. policy move induces foreigners to respond in kind. The effects in this case are quite different. The symmetric aspect of the two policies implies much smaller changes in the trade balance and other components of the balance of payments. Accordingly, the changes in nominal and real exchange rates are small. While net flows show little change, gross international flows change substantially. Because the changes in gross flows largely offset each other, there is relatively little change in available funds to U.S. firms, and before-tax U.S. interest rates change very little.

Global imposition of withholding leads to significant changes in welfare. As indicated in Table 3, aggregate domestic as well as foreign welfare decline. A companison of the results in the two alternative exper-

29 A nation's current account is the change in its net foreign asset position. This relationship implies that the present value of a nation's prospective trade balances must equal the negative of its current net foreign asset position. Thus, when the net foreign asset position improves, the trade balance can be lower on average. 
iments makes clear that from the point of domestic welfare, the attractiveness of the withholding tax option depends fundamentally on the extent to which it induces foreign retaliation.

3. Sensitivity Analysis. Table 4 shows the sensitivity of results to changes in key parameters. As predicted, lower asset substitutability increases U.S. financial market power, enabling U.S. capital markets to clear with smaller increases in before-tax interest rates. Greater U.S. market power implies lower foreign welfare. The extent of (inframarginal) tax credits to foreigners has relatively little influence on U.S. inter-

\section{TABLE 4}

\section{Sensitivity Analysis}

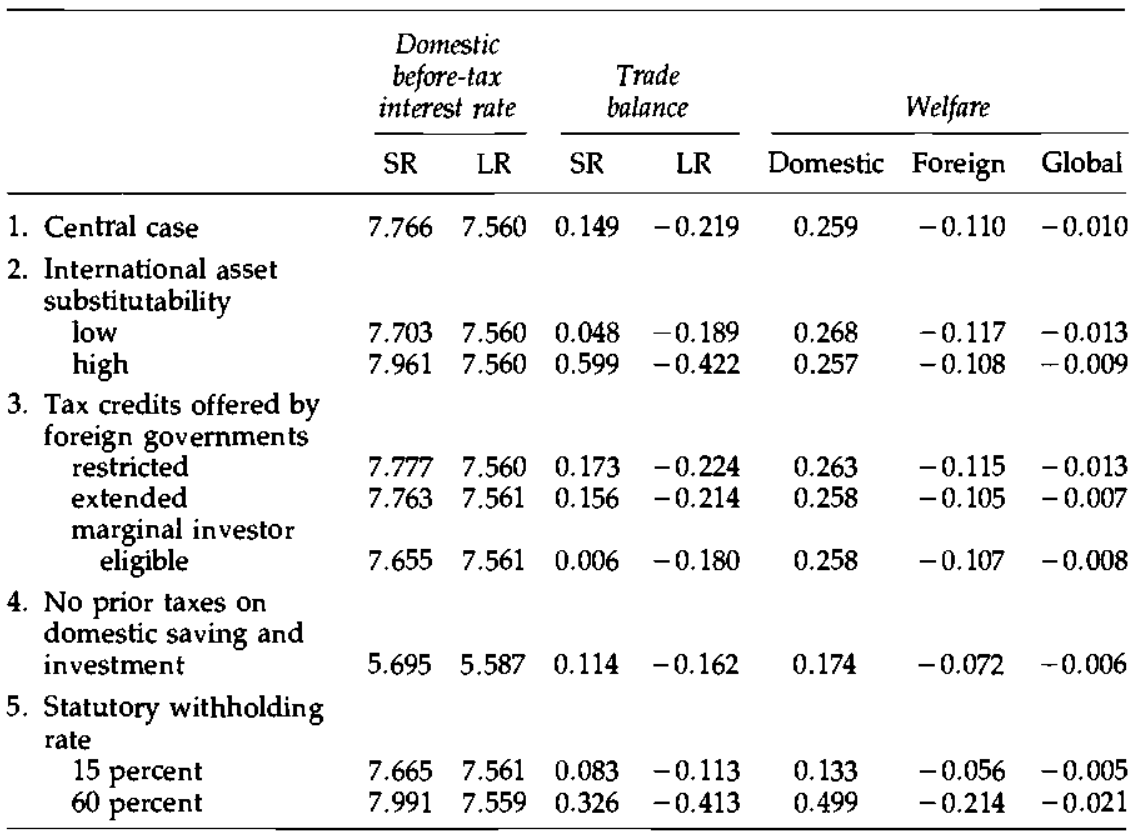

"SR" and 'LR" denote the first period following the policy change and the new steady state. The status quo or base case value for the domestic interest rate is 7.56 percent, except in the "no-prior-taxes" experiment, for which the base case interest rate is 5.587 percent. In the central case, the elasticity of substitution between domestic and foreign assets in the foreigner's portfolio preference function is unity, the foreign government offers tax credits to foreigners for 60 percent of the value of withholding taxes paid to the U.S., the marginal foreign investor is assumed to be ineligible for tax credits, and the statutory withholding tax rate is 30 percent. The low and high asset substitutability cases assume values of 0.5 and 4.0 for the asset substitution parameter. In the restricted and extended tax credit cases, 30 percent and 90 percent of the value of withholding taxes paid are eligible for tax credits. In the case where the marginal foreign investor is eligible for credits, still only 60 percent of (inframarginal) withholding taxes paid are offset by foreign tax credits. 
est rates. Foreign residents' welfare improves slightly with more extensive credits. ${ }^{30}$ Treating the marginal foreign investor as eligible for the credits leads to significantly different initial interest rate effects, as expected: the U.S. interest rate need not rise much, since under these circumstances the withholding tax has no first-order effect on the aftertax return to the foreign investor. Here the withholding tax does little to deter foreign investment in the U.S.; hence no serious capital account deficit arises, and the nation can afford to run a trade deficit, even in the short term. ${ }^{31}$ A simulation performed under the counterfactual specification of no prior taxes on domestic saving and investment leads to smaller welfare gains from withholding. This suggests that, in the presence of saving and investment taxes, the gains from withholdingtax-induced increases in domestic saving outweigh the losses from induced reductions in domestic investment. Finally, the pattern of interest rate, trade balance, and welfare effects is essentially the same under different statutory withholding rates, although magnitudes differ.

The sensitivity analysis shows that two main results from these experiments are robust. In all experiments, the policy change ultimately worsens the trade balance. In addition, the unilateral initiative considered here consistently leads to domestic welfare gains. Still, these results should be interpreted with caution. Results are sensitive to assumptions about the extent of asset substitutability, and very high values could reverse the sign of the welfare effect. ${ }^{32}$ In addition, the lack of an explicit treatment of banking institutions and other financial intermediation is a significant limitation in evaluating this withholding initiative. It should also be kept in mind that all simulations assume balanced budgets on the part of the U.S. and foreign governments: revenue-expenditure balance is maintained through lump-sum tax adjustments. Hence these experiments do not account for possible welfare effects associated with the withholding tax's ability to alter public sector budget imbalances (the U.S. budget deficit in particular). These results should be regarded as suggestive rather than definitive.

${ }^{30}$ One might expect higher credits to imply lower foreign welfare. In the model, the potentially adverse effects of higher credits are minimized because the credits are financed through lump-sum taxes, which have no direct adverse efficiency consequences.

${ }^{31}$ The trade balance is slightly positive in year 1 but is negative in all subsequent years.

${ }^{32}$ For technical reasons, we were unable to employ values larger than 4.0 for the asset substitutability parameter. Employing very large values currently leads to instability in the algorithm used to solve for economic equilibria. One hopes that a technical breakthrough is not far away. 


\section{ADOPTING A MORE GLOBAL PERSPECTIVE}

The approach taken in the last two sections to evaluate the withholding tax option might be considered narrow in at least two respects. First, it employed a somewhat restrictive notion of U.S. welfare. Considerations of international fairness, of the good (or bad) will stemming from perceptions of fairness (or inequity), and of the global efficiency of resource allocation were omitted from the previous assessments of the tax.

Second, the previous sections evaluated the policy option only in comparison with the status quo, whereas a broader examination might expand the domain of alternatives to include coordinated policy initiatives undertaken cooperatively by the U.S. and other nations. Such initiatives might lead to more favorable outcomes (domestically and globally) than the non-cooperative policy actions scrutinized thus far. This section takes a broader perspective, investigating some issues that may be critical to the overall attractiveness of the withholding tax option.

\section{A. A Beggar-Thy-Neighbor Policy or a Quid-Pro-Quo Response?}

The simulation results from the previous section indicate that a unilateral withholding tax would generate welfare losses to foreigners that largely offset the domestic welfare gains. It is hard to justify unilateral introduction of the tax on the grounds of global efficiency, since the reductions in foreign wealth and welfare match the domestic gains. The unilateral policy has an unappealing beggar-thy-neighbor quality.

The initiative gains some appeal to the extent that it is applied selectively, only to residents of those countries that already impose similar levies on the interest income of U.S. residents. A selective withholding tax seems less unfair. Table 5 shows the withholding taxes that 25 (mainly industrialized) countries apply to income earned from U.S. portfolio investments in those countries. The table reveals considerable variation in the treatment of interest income. Three of the nations offer a blanket exemption for interest income. Nine others exempt such income as a result of treaties with the U.S. Twelve countries tax interest income at rates of ten percent or higher. The table suggests that if a U.S. tax on foreigners' portfolio interest were imposed selectively, it might apply to about half of the major nations involved in international financial transactions with the U.S.

\section{B. Global Efficiency}

However, whether or not it is imposed selectively, a withholding tax on interest income is not attractive in terms of the global efficiency of capital 


\section{TABLE 5}

Foreign Withholding Rates on U.S.-Owned Capital Under U.S. Income Tax Treaties (as of January 1, 1988)

\begin{tabular}{|c|c|c|c|}
\hline Country & $\begin{array}{c}\text { Dividends } \\
\%\end{array}$ & $\begin{array}{c}\text { Interest } \\
\%\end{array}$ & $\begin{array}{c}\text { Patent and } \\
\text { Know-How } \\
\text { Royalties } \\
\%\end{array}$ \\
\hline Australia & 15 & 10 & 10 \\
\hline Austria & 10 & $\mathbf{E}$ & $\mathbf{E}$ \\
\hline Belgium & 15 & 15 & $\overline{\mathbf{E}}$ \\
\hline Canada & 15 & 15 & 10 \\
\hline China & 10 & 10 & 10 \\
\hline Cyprus & 0 & 10 & 0 \\
\hline Denmark & 15 & $\mathbf{E}$ & $\mathbf{E}$ \\
\hline Egypt & N/A & 15 & 15 \\
\hline Finland & 15 & 0 & 0 \\
\hline France & 15 & 0 & 5 \\
\hline Germany (West) & 15 & $\mathbf{E}$ & $\mathbf{E}$ \\
\hline Greece & N/A & $\mathbf{E}$ & $\mathbf{E}$ \\
\hline Ireland & N/A & $\mathbf{E}$ & $\mathbf{E}$ \\
\hline Italy & 15 & 15 & 10 \\
\hline Japan & 15 & 10 & 10 \\
\hline Korea (South) & 15 & 12 & 15 \\
\hline Luxembourg & 7.5 & $\mathbf{E}$ & $\mathbf{E}$ \\
\hline Netherlands & 15 & $\mathbf{E}$ & $\bar{E}$ \\
\hline New Zealand & 15 & 10 & 10 \\
\hline Norway & 15 & 0 & $\mathbf{E}$ \\
\hline Philippines & 25 & 15 & 25 \\
\hline Sweden & 15 & $\mathbf{E}$ & $\mathbf{E}$ \\
\hline Switzerland & 15 & 5 & $\mathbf{E}$ \\
\hline Trinidad \& Tobago & 25 & 15 & 15 \\
\hline United Kingdom & 15 & $\mathbf{E}$ & $\mathbf{E}$ \\
\hline
\end{tabular}

Definitions:

$\mathrm{E}$, The income is exempt from withholding tax under the treaty. N/A, The treaty does not limit the tax applicable to this type of income.

Note: Rates apply to both individual and corporate investors. Source of data is Ernst \& Whinney, 1988 Foreign and U.S. Corporate Income and Withholding Tax Rates.

allocation. The policy experiments described in the previous section attest to this result: for example, simulations of a unilateral expansion of the U.S. withholding tax led to no increase in global welfare. A reason for the global inefficiency of the withholding tax is that it departs from the residence principle of taxation, which has some desirable efficiency properties. When taxed on a residence basis, households pay taxes on their worldwide income, and their tax obligations are to the governments of their country of residence. Universal adoption of the residence 
principle in the taxation of capital income tends to promote a more efficient global allocation of capital by inducing equality of pre-tax rates of return on capital, even when nations' tax rates differ. ${ }^{33}$

The withholding tax does not adhere to the residence principle. The tax is source-based: an individual's withholding tax obligations are to the country in which the income is generated, not the country of residence. When nations impose different tax rates, source-based taxation cannot be relied upon to produce a globally efficient allocation of capital: pre-tax returns will generally not be equated. Introducing withholding taxes leads tax systems away from the residence principle and is likely to imply a reduction in the global efficiency of capital allocation. This adverse effect is mitigated to the extent that foreign governments allow their residents to credit withholding taxes paid to the U.S. ${ }^{34}$

A second major reason for the global efficiency losses has to do with the changes in the overall level of capital taxation brought about by expanding the withholding tax. While the previous discussion of residence-based taxation was linked to the efficiency in the static international allocation of capital, the issue of the overall level of capital taxation bears on the efficiency in the intertemporal allocation of capital. Insofar as they raise the overall level of capital taxation, expanded withholding taxes may reduce the intertemporal efficiency of resource allocation, leading to lower levels of saving and investment than that which would maximize welfare over time. ${ }^{35}$ In the simulations reported in the previous section, the expanded withholding tax did indeed augment the overall level of capital taxation because the additional taxes were not

${ }^{33}$ See Bovenberg (1989b), Giovannini (1989), and Mintz (1986) for a discussion of the efficiency of residence-based (and source-based) taxation. Although universal adoption of residence-based taxation may yield a "neutral" tax environment in the sense that pre-tax rates of return are equal across countries and industries, if consumption-side taxes are not optimal or if different types of capital goods are not equally complementary to labor in production, neutrality of this type is generally sub-optimal. On this point see Auerbach (1988). Furthermore, multinational firms introduce complications, and residence-based taxation of such firms cannot guarantee production efficiency (see Mintz [1986]).

It may be noted that the OECD, in its 1977 Model Double Taxation Convention on Income and on Capital, endorsed the residence principle for interest income flows as a rule for double taxation treaties.

${ }^{34}$ When foreign governments allow their residents to credit 100 percent of withholding taxes paid to the U.S., the marginal tax rate faced by foreigners on investments in the U.S. is that of the home (foreign) country. In this case the efficiency properties of residencebased taxation are retailed.

${ }^{35}$ If agents effectively face infinite horizons, capital allocation is intertemporally efficient in the absence of taxes. Capital income taxes may lead to a path of consumption that is suboptimal in terms of intertemporally defined utility: there will be too much present consumption (too little saving) and too little future consumption. See Sandmo (1976). 
offset by reductions in other capital taxes. ${ }^{36}$ Thus, the policy initiative is likely to have led to a reduction in the efficiency in the intertemporal as well as the international allocation of capital. ${ }^{36 a}$

\section{Are Efficiency and Fairness Goals Reconcilable?}

These considerations suggest a conflict between efficiency and equity goals. While it may seem fair for the U.S. to impose additional withholding taxes selectively on residents of countries which impose similar taxes, doing so may well worsen the global efficiency of resource allocation. The outcome does not appear to be fully satisfactory. Are there other worthwhile options?

One alternative worth considering involves international tax coordination. A principal goal of such coordination would be achieving a wider international application of the residence principle. One means to this end would be removal of withholding taxes by those nations that currently impose them. To the extent that other nations agree to such measures, there is less justification on equity grounds for an expanded U.S. tax. However, until multilateral reductions in withholding taxes are agreed to, the temporary introduction of U.S. withholding on portfolio interest might have some value as a bargaining chip. But such U.S. withholding would not be intended as a permanent fixture.

Unfortunately, in the context of the withholding tax, international policy coordination faces serious political obstacles. Nations removing existing withholding taxes face the dilemma of reduced tax revenues or of having to increase other taxes. The prevalence of withholding taxes may stem from the fact that they involve relatively small political costs: those who must pay these taxes have a relatively small political voice within the country in question. Replacing withholding taxes with taxes on domestic residents, on the other hand, may involve very large political costs. Thus the political barriers to greater adoption of residencebased taxation through the removal of withholding taxes are formidable.

\footnotetext{
${ }^{36}$ The policy simulations involved lump-sum reductions in individual labor and capital income taxes. These adjustments were made at the level necessary to assure that in each policy experiment, total tax revenues to each country were the same as those collected in each country in the base (status quo) case. Because these adjustments were lump-sum and not restricted to capital, the simulations implied an increase in overall (inclusive of the withholding tax) capital taxation.

${ }^{36 a}$ Higher capital taxes may permit given levels of government expenditure to be provided with lower taxes on labor. The efficiency losses attributable to higher capital taxes can conceivably be offset by efficiency gains from lower labor taxes. The model employed in this paper does not capture these potential offsetting effects, since household labor supply is exogenous.
} 


\section{Tax Evasion and Capital Flight}

Several analysts have pointed out that a significant amount of foreign investment in the U.S. is undertaken in order to evade taxation in the country of residence. ${ }^{37}$ Many nations that officially adopt the residence principle have difficulty preventing tax evasion because of limited information concerning income earned from abroad: if investments made outside the country of residence are not monitored, then such investments can provide a vehicle for escaping taxes. This problem is particularly severe for less developed countries (LDCs). The cost is not simply a loss of tax revenues but also a lower rate of domestic capital accumulation and growth.

These difficulties reverse the usual fairness arguments about withholding. Referring to the tax evasion problem, some analysts contend that fairness considerations argue for the expansion of a U.S. withholding tax. If the U.S. withholds foreigners' interest income, it is no longer possible to escape capital income taxation by investing in the U.S. Thus, U.S. withholding of portfolio interest has the virtue of discouraging tax evasion and capital flight.

The problems of tax evasion and capital flight are indeed serious. However, introducing a U.S. withholding tax on portfolio interest may not be the most effective remedy for these difficulties. The evasion problem ultimately stems from a lack of information on foreign investments; the most natural solution may be to develop better ways to monitor investments in the U.S. and provide information on these investments to foreign governments. Certainly providing information would not eliminate all tax evasion, capital flight to the U.S., or capital flight to other countries. But such efforts would appear to be at least as effective in addressing these problems as an expanded U.S. withholding tax. At the same time, it would avoid many of the inefficiencies that enlarging the U.S. withholding tax would generate.

However, any unilateral efforts undertaken by the U.S. are likely to be limited in their effectiveness in dealing with tax evasion problems. So long as other nations continue to offer favorable investment opportunities, unilateral provision of information or expansion of the U.S. withholding tax would have the effect of inducing investors from LDCs to redirect their investments from the U.S. to other nations. Only through cooperative efforts on the part of all "tax haven" countries can these problems be addressed effectively. ${ }^{38}$

${ }^{37}$ See, for example, Bird and McLure (1988) and McLure (1989).

${ }^{38}$ See McLure (1989) for a detailed discussion of this issue. 


\section{CONCLUSIONS}

The complexities of international financial markets and of international politics make evaluating the withholding tax option a difficult matter. Existing treaty provisions as well as tax-avoidance options on both the supply and demand sides of securities markets substantially limit the opportunities to obtain additional revenues through expansion of the U.S. withholding tax.

The introduction of a statutory 30 percent U.S. withholding tax on foreigners' interest income, if not accompanied by similar (retaliatory) tax measures by foreign governments, appears to yield aggregate domestic welfare gains. The gains are attributable to U.S. financial market power and to induced increases in domestic saving. U.S. market power stems from the large share represented by the U.S. of world financial transactions and from the imperfect substitutability between U.S. and foreign securities in portfolios. Simulations suggest that these gains more than compensate for adverse distortionary effects of the tax. Although the tax initially has a favorable effect on the U.S. trade balance and aggregate exports, it ultimately has the opposite effect. The common proposition that a withholding tax would help relieve the U.S. trade deficit appears to be valid only for the short term.

On the other hand, if foreign governments respond in kind to the U.S. introduction of withholding on portfolio interest, U.S. residents' aggregate welfare declines. Under these circumstances, effects on net trade flows and on the U.S. net foreign asset position are much smaller.

Regardless of whether it is matched by similar measures by foreign governments, expanding the U.S. withholding tax seems to imply a reduction in the global efficiency of resource allocation. The efficiency costs may arise because the tax represents a departure from the residence principle of taxation (to the extent that foreign governments do not provide credits for U.S. withholding taxes paid) and because it implies an increase in the overall level of capital taxation.

The equity arguments for the withholding tax are mixed. An unappealing feature of a unilateral U.S. withholding tax initiative is that the gains in U.S. welfare come at the expense of foreigners. Restricting the application of the tax to investors from countries that already impose similar measures may have more justification on fairness grounds than applying the tax to all foreign investors. An attraction of the tax is its ability to discourage capital flight to the U.S. and associated tax evasion; however, other policies with less serious efficiency costs might be equally effective in addressing tax evasion problems. 


\section{APPENDIX}

\section{Welfare Implications of Financial Market Power of U.S.}

Define $r_{m}$ as the return paid to foreigners on $K_{m}$, U.S. capital imports; $r_{m}$ is therefore the U.S. interest rate net of the withholding tax. Define $r_{x}$ as the return paid to U.S. residents on $K_{x}$, U.S. capital exports (U.S. residents' portfolio investments abroad); if foreigners do not impose withholding taxes, this is simply the gross rate of return offered abroad translated into dollars. By calculating the foreign rate in dollar terms, one avoids the need to consider exchange rate movements explicitly.

A large share of world financial transactions and imperfect substitutability between domestic and foreign securities can (each) alter the welfare effects of a withholding tax through their influence on $r_{x} K_{x}-r_{m} K_{m}$, the value of net interest income to the U.S. Large market share enables a U.S. withholding tax to drive down the rates $r_{m}$ and $r_{x}$. If securities are perfect substitutes, then $r_{m}$ must equal $r_{x}$. The welfare influence depends on the induced change in $r_{x} K_{x}-r_{m} K_{m}$, and since $r_{x}=r_{m}$, it depends on the change in $r\left(K_{x}-K_{m}\right)$, where $r$ represents the common international interest rate. If the U.S. is a net capital exporter $\left(K_{x}>K_{m}\right)$ and the tax doesn't alter much the difference between $K_{x}$ and $K_{m}$, then the induced reduction in $r$ lowers net interest income and thereby has a negative influence on welfare. The reverse is the case for a net capital importer.

Imperfect asset substitutability enables the U.S. to force down $r_{m}$ below the rate $r_{x}$. This is possible even when the U.S. share of world financial transactions is small. Again, the influence on welfare depends on the induced change in $r_{x} K_{x}-r_{m} K_{m}$. Ceteris paribus, lower asset substitutability allows for a larger relative reduction in $r_{m}$. This implies an increase in domestic net interest income. Thus, lower asset substitutability tends to exert a positive influence on the domestic welfare effects of withholding.

\section{Welfare Implications of Prior Taxes on Domestic Saving and Investment}

a. Prior Taxes on Saving. Figure 3a indicates the economic equilibria that result in the presence and absence of pre-existing taxes on domestic saving. The OCS and MPC schedules represent the opportunity cost of saving and marginal product of capital, as before. In the absence of taxes, these schedules correspond to supply curves for domestic saving and investment. For an economy that is a price-taker in capital markets, equilibrium domestic saving and investment are at levels $S_{D 1}$ and $I_{D 1}$. Introducing a withholding tax at the rate $t_{w}$ yields equilibrium saving 
Implications of Introducing Withholding Taxes

137

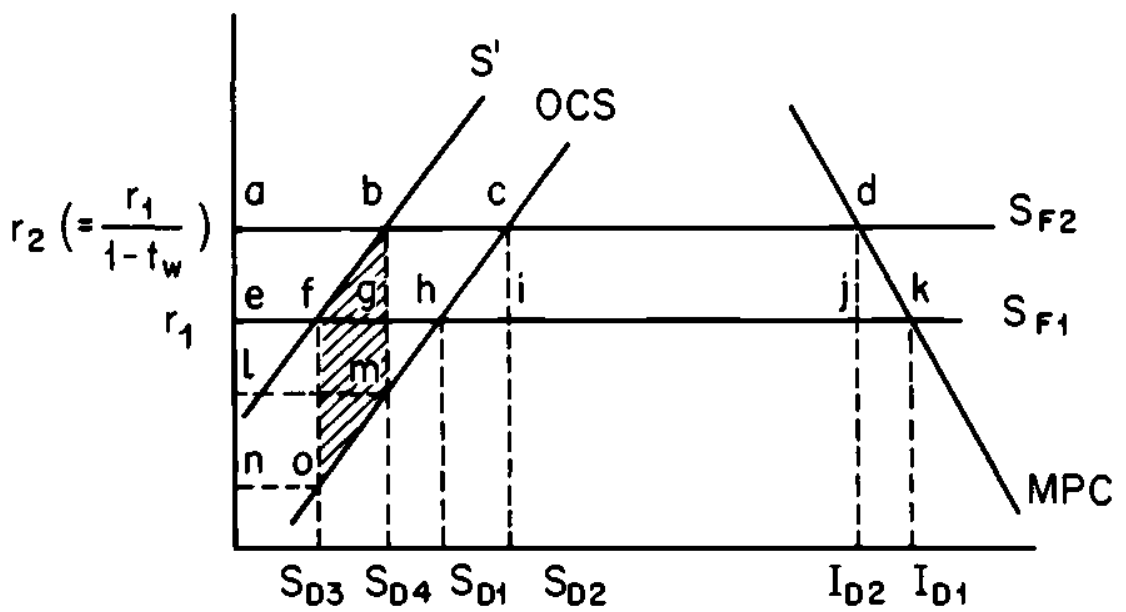

FIGURE Ba. Effects of Withholding Tax in Presence of Prior Saving Taxes

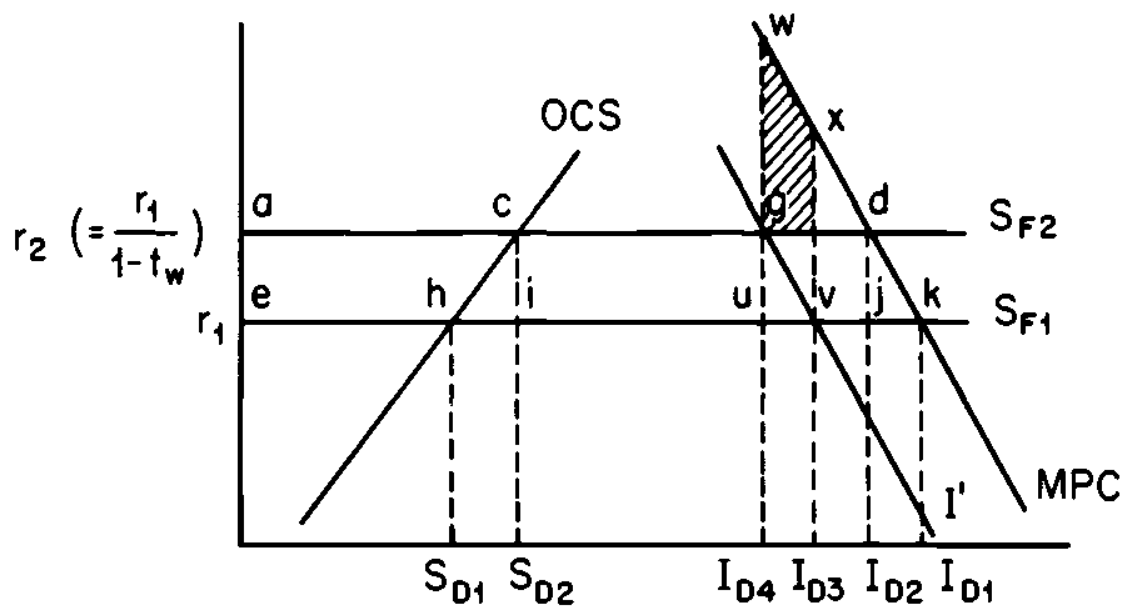

FIGURE Bb. Effects of Withholding Tax in Presence of Prior Investment Taxes 
and investment of $S_{D 2}$ and $I_{D 2}$. The aggregate welfare loss is given by the triangular regions $c i h$ and $d k j$, corresponding to the regions $B$ and $D$ described previously in Section III.

The implications of a prior tax on domestic saving are as follows. The domestic supply curve is now $S^{\prime}$, where the horizontal distance between $S^{\prime}$ and OCS is the tax paid per unit of saving. In the absence of withholding, equilibrium domestic saving is now $S_{d 3}$, while equilibrium domestic investment is still $I_{D 1}$. Introducing a withholding tax in this environment leads to a new equilibrium with domestic saving and investment of $S_{D 4}$ and $I_{D 2}$, respectively. Under these conditions, domestic savers gain the region Imon, which, if saving taxes are proportional, corresponds to the region abfe. Domestic borrowers, as before, lose adke. Taxpayers gain the withholding tax revenues $c d j i+f b m o$ (shaded region), the taxes collected on the additional saving $S_{D 4}-S_{D 3}$. The aggregate welfare loss is $b f g+d k j$ less the additional saving taxes, fbmo. Under proportional saving taxes, bgf corresponds to cih; thus, the difference between the aggregate welfare effect in this case and in the case without prior saving taxes is fbmo. This area is the gain associated with realizing the excess of the marginal social benefit of saving over its marginal social cost as domestic saving rises from $S_{D 3}$ to $S_{D 4}$.

A similar analysis can be employed to show that prior progressive saving taxes do not augment the potential gains (or reduce the losses) from a withholding tax as much as prior proportional saving taxes do: the improvement in welfare relative to the case of no prior saving taxes will be less than the value of the induced new saving taxes.

b. Prior Taxes on Investment. The analysis for prior investment taxes is analogous. Figure $3 b$ indicates the economic equilibria in the presence and absence of such prior taxes. If there are no prior taxes, equilibrium saving and investment are $S_{D 1}$ and $I_{D 1}$ with no withholding and $S_{D_{2}}$ and $I_{D 2}$ following the imposition of a withholding tax.

With a tax on investment, the investment schedule is $I^{\prime}$ and equilibrium domestic saving and investment are $S_{D 1}$ and $I_{D 3}$ before withholding. Implementing the withholding tax leads to the equilibrium with saving and investment of $S_{D_{2}}$ and $I_{D 4}$. Domestic savers gain ache and domestic borrowers lose aqve. Taxpayers gain cqui in withholding tax revenues but lose the revenues $w x v q$ (shaded region) that previously were collected from the investment tax. The aggregate loss is cih $+q v u$ plus wxvq, the lost investment tax revenues. Under proportional investment taxes, qvu equals $d k j$; hence in these circumstances pre-existing investment taxes imply that aggregate welfare losses will be larger by the amount of foregone investment tax revenue, wxvq. This area is the 
loss associated with the failure to enjoy the excess of the marginal social benefit of investment over its marginal social cost for potential investments from $I_{D 4}$ to $I_{D 3}$. A similar analysis reveals that under progressive investment taxes, the aggregate welfare losses exceed the losses with no prior investment taxes by an amount less than the value of foregone investment tax revenue.

\section{REFERENCES}

Auerbach, A. J. 1988. The deadweight loss from "non-neutral" capital income taxation. National Bureau of Economic Research working paper no. 2510. February.

Bird, R. M. and C. E. McLure, Jr. 1989. The personal income tax in an interdependent world. Mimeo.

Bovenberg, A. L. 1989a. The effects of capital income taxation on international competitiveness and trade flows. American Economic Review 79 (forthcoming).

. 1989b. International coordination of tax policies. International Monetary Fund. Mimeo.

Bovenberg, A. L. and L. H. Goulder. 1989. Promoting investment under international capital mobility: An intertemporal general equilibrium analysis. National Bureau of Economic Research working paper no. 3139. October.

Brean, D. J. S. 1984. International issues in taxation: The Canadian perspective. Canadian tax paper no. 75. Canadian Tax Foundation.

Carson, M. P. 1985. Foreign recipients of U.S. income, and tax withheld, 1984. SOI Bulletin. Department of the Treasury, Internal Revenue Service, vol. 5, no. 2. pp. 61-77.

Giovannini, A. 1989. National tax systems vs. the European capital market. Economic Policy. October.

Goulder, L. H. and B. Eichengreen. 1989a. Savings promotion, investment promotion and international competitiveness. In Trade policies for international competitiveness, R. Feenstra, ed. Chicago: University of Chicago Press.

- $1989 \mathrm{~b}$. Final report for phase II research on a computable general equilibrium model for analyzing dynamic responses to trade policy and foreign competition. Prepared for Bureau of International Labor Affairs of the U.S. Department of Labor.

King, M. A. and D. Fullerton. 1984. The taxation of income from capital. Chicago: University of Chicago Press.

Lewis, M. P. 1986. Foreign recipients of U.S. income, and tax withheld. SOI Bulletin. Department of the Treasury, Internal Revenue Service, vol. 6, no. 2. pp. 61-77.

McLure, C. E., Jr. 1989. U.S. tax laws and capital flight from Latin America. Inter-American Law Review 20 (2), University of Miami.

Mintz, J. M. 1986. Corporate tax design in an international setting: tax competition and the openness of the economy. Kingston, Ontario: Queens University. Mimeo. June.

Papke, L. E. 1988. International differences in capital taxation and corporate borrowing behavior: Evidence from the U.S. withholding tax. Boston: School of Management, Boston University. Mimeo. 
Sandmo, A. 1976. Optimal taxation-and introduction to the literature. Journal of Public Economics 6. pp. 37-54.

Scholl, R. B. 1984. The international investment position of the U.S. in 1983. Survey of Current Business. June. pp. 74-77.

1985. The international investment position of the U.S. in 1984. Survey of Current Business. June. pp. 25-33.

- 1986. The international investment position of the U.S. in 1985. Survey of Current Business. June. pp. 26-35.

. 1988. The international investment position of the U.S. in 1987. Survey of Current Business. June. pp. 76-84.

_ 1989 . The international investment position of the U.S. in 1988. Survey of Current Business. June. pp. 41-49.

Sinn, H. W. 1988. The 1986 U.S. tax reform and the world capital market. European Economic Review 32. pp. 325-33.

Summers, L. H. 1981. Taxation and corporate investment: A q-theory approach. Brookings Papers on Economic Activity. (January): 67-127. 
Tax

Policy

and the Economy

\section{Edited by Lawrence H. Summers}

National Bureau of Economic Research

Of related interest

Tax Policy and the Economy, Volume 3

Edited by Lawrence $\boldsymbol{H}$. Summers

Articles by Martin Feldstein and Douglas Elmendorf;

Daniel Feenberg and Jonathan Skinner; James $M$.

Poterba; B. Douglas Bernheim; John B. Shoven

Tax Policy and the Economy, Volume 2 Edited by Lawrence $\boldsymbol{H}$. Summers

Articles by B. Douglas Bernheim; James R. Hines, Jr.; Don Fullerton and Andrew B. Lyon; Roger H. Gordon and Joel Slemrod; Lawrence B. Lindsey; Laurence J. Kotlikoff and David A. Wise

The MIT Press, Cambridge, Massachusetts 02142 